\title{
Implications for the assay and biological activity of interleukin-4 Results of a WHO international collaborative study
}

\author{
Anthony R. Mire-Sluis ${ }^{\text {a, }}{ }^{*}$, Rose Gaines Das ${ }^{\text {b }}$, Robin Thorpe ${ }^{\text {a }}$, \\ Participants ${ }^{1}$ of the Study \\ ${ }^{a}$ Division of Immunobiology, National Institute for Biological Standards and Control, Blanche Lane. South Mimms, Potters Bar, Herts EN6 \\ $3 Q G, U K$ \\ ${ }^{b}$ Informatics Laboratory, National Institute for Biological Standards and Control, Blanche Lane, South Mimms, Potters Bar, Herts, EN6 \\ 3QG. UK
}

Received 25 January 1996; accepted 19 March 1996

\begin{abstract}
Five ampouled preparations of interleukin-4 (IL-4) have been evaluated by 36 laboratories in 14 countries for their suitability to serve as an international standard for this material in a joint international collaborative study for interleukin-3 (IL-3) and IL-4. The preparations were assayed in a wide range of in vitro bioassays and immunoassays. It is clear from the study that different recombinant preparations of IL-4 can have very different biological specific activities, including those from the same source (i.e., E. coli). In addition, immunoassay estimates of IL-4 levels did not correlate with those of bioassays, illustrating the fact that immunoassays do not necessarily measure biologically active cytokine. It is of interest that the estimates provided by the different bioassays were less variablc than those produced by the immunoassays, suggesting that bioassays can be as accurate. if not more so, than immunoassays. The large reduction in the variability of estimates with the inclusion of a single reference preparation clearly illustrates the need for a single standard to assay IL-4. On the basis of the results reported here, with the agreement of the participants of the study and with the authorisation of the Expert Committee on Biological Standardization (ECBS) of the World Health Organization (WHO) the preparation of IL-4 $(88 / 656)$ was established as the international standard for interleukin-4 with an assigned unitage of 1000 IU/ampoule.
\end{abstract}

Kevwords: IL-4; Standardization

\section{Introduction}

Interleukin-4 (IL-4) is a T lymphocyte derived polypeptide possessing a broad spectrum of biologi-

Abbreviations: IL-3, interleukin-3; IL-4, interleukin-4: $\mathbf{R h}$, rDNA derived human; HSA, human serum albumin.

* Corresponding author. Tel.: + 44-(707)654753; Fax: + 44(707) 646730 .

${ }^{1}$ Listed in Table 2. cal activities (Howard et al., 1982; Yokota et al., 1988). In addition to inducing proliferation of human $B$ cells, it can stimulate the proliferation of a wide range of cells such as $\mathrm{T}$ lymphocytes, mast cells and haemopoietic progenitor cells (Ohara, 1988). The gene for IL-4 has been cloned and shown to code for a 129 amino polypeptide which is glycosylated and has a molecular mass of $15-22 \mathrm{kDa}$ (Yokota et al., 1986; Ohara et al., 1987). IL-4 also has the ability to activate anti-tumour macrophages and inhibit the 
growth of several different types of tumour cells such as lung tumours, renal cell carcinoma and B lymphomas (Golumbek et al., 1991; Defrance et al., 1992; Toi et al., 1992; Topp et al., 1993). This has led to clinical investigations of the therapeutic anticancer potential of IL-4 (Gilleece et al., 1992; Margolin et al., 1994).

The majority of bioassays for IL-4 utilise cell lines and thus avoid the donor variation of natural cell preparations (Avanzi et al., 1988; Siegel and Mostowski, 1990). There are several methods for detecting the activity of IL-4 due to its plietotropic biological properties. IL-4 can induce proliferation, inhibit proliferation, induce expression of proteins on the cell surface and promote secretion of proteins extracellularly (Avanzi et al., 1988: Topp et al., 1993; Siegel and Mostowski, 1990).

This collaborative study included several different cell line based assays, assays using natural material and immunoassays.

\section{Aims of the study}

The aims of the study were to:

1. assess the suitability of the ampouled preparations to serve as international standards (IS) for the bioassay and immunoassay of IL-4;

2. to assay the IL-4 content of the ampouled preparations;

3. to compare the different assay systems for IL-4;

4. to compare the ampouled preparations with local standards.

\section{Materials and methods}

\subsection{Materials for the study}

Generous gifts of rDNA derived human rhIL-4 were kindly donated by Immunex (USA), Schering Plough (USA), Innogenetics (Belgium), Sandoz (Switzerland) and Glaxo (UK) and rhIL-3 donated by Immunex (USA). The candidate international standards were ampouled according to the procedures used for international biological standards (Annex 4, 40th ECBS Report. 1990) and coded as detailed in Table 1.
Each preparation of rhIL-4 or rhIL-3 was dissolved in 2 or 4 litres of pyrogen-free saline $(0.9 \%$ $\mathrm{NaCl}$ ) pH 7.2 (Travenol Laboratories, Thetford, Norfolk, UK) containing $0.2 \%$ clinical grade human serum albumin and $0.1 \%$ trehalose (Fluka Chemicals, Glossop. Derbyshire, UK). This solution was distributed in $0.5 \mathrm{ml}$ or $1 \mathrm{ml}$ aliquots into 4000 ampoules. The ampouled solution was lyophilised and, after secondary desiccation, the ampoules were sealed under dry nitrogen by heat fusion of the glass and stored at $-20^{\circ} \mathrm{C}$ in the dark.

$88 / 656$ has been distributed for use as an interim reference reagent with an assigned unitage of 1000 $\mathrm{U} /$ ampoule.

\subsection{Participants in the study}

48 laboratories in 16 countries contributed data as part of a joint IL-3 and IL-4 collaborative study (Table 2). Of these participants, 16 provided assays for both the IL-3 and IL-4 preparations, 12 provided assays for IL -3 preparations only. and 20 provided assays for IL-4 preparations only. In addition, one laboratory (NIBSC) provided additional data on stability. Throughout this report of the study, each laboratory has been identified by a number from 01 to 48 , not related to the order of listing in Table 2 . Results reported here include only those from assay systems which were either specific for IL-4 or which gave responses to both IL-3 and IL-4.

\subsection{Design of the study}

Participants were asked to contribute assays for IL-4. These were to include both bioassays and immunoassays, especially if the latter were unique to the laboratory of the participant with respect to the antibodies used.

Each participant was asked to carry out at least two independent assays each including, as far as possible, all of the preparations to be tested. For this study assays were considered independent if the dilutions of the various materials were made from a freshly prepared ampoule or fresh dilutions from an appropriately stored stock solution. Participants were requested to include preferably no less than five dilutions of each ampoule in the linear portion of the dose-response curve. 
Table 1

Material included in the study

\begin{tabular}{lllll}
\hline Study code & Ampoule code & Residual moisture content & Coefficient of variation & $\begin{array}{l}\text { Nominal IL-3 or IL-4 } \\
\text { content of ampoule }\end{array}$ \\
\hline $\mathrm{F}$ & $88 / 780$ & $0.33 \%$ & $0.21 \%$ & $1 \mu \mathrm{g}$ yeast IL-3 Pro Asp $_{15 / 70}$ \\
$\mathrm{G} / \mathrm{M}$ & $88 / 656$ & $0.20 \%$ & $0.15 \%$ & $100 \mathrm{ng} \mathrm{CHO} \mathrm{IL-4}$ \\
$\mathrm{H}$ & $88 / 682$ & $0.26 \%$ & $0.16 \%$ & $100 \mathrm{ng}$ E. coli $\mathrm{IL}-4$ \\
$\mathrm{~J}$ & $89 / 508$ & $0.33 \%$ & $0.11 \%$ & $1 \mu \mathrm{g}$ yeast IL-4 Glu, Ala $\mathrm{Glu}_{3} \mathrm{Ala}_{4} \mathrm{Asp}_{38 / 105}$ \\
$\mathrm{~K}$ & $89 / 668$ & $0.15 \%$ & $0.13 \%$ & $1 \mu \mathrm{g} \mathrm{E.} \mathrm{coli}$ IL-4 \\
$\mathrm{L}$ & $92 / 576$ & $0.24 \%$ & $0.17 \%$ & $100 \mathrm{ng}$ E. coli $\mathrm{IL}-4$ \\
\hline
\end{tabular}

The coefficient variation (CV) is defined as: $\mathrm{CV}=$ standard deviation $\div$ mean (ECBS Technical Report Series 800, 1990, pp. 181-208).

Participants were asked to contribute all raw data in standard format together with detailed descriptions of assay methods, including their own calculated estimates of potency.

Included among the coded ampoules were unlabelled ampoules containing formulation without the active component in order to highlight non-specific effects in the assays.

\subsection{Assavs contributed to the study}

Details of the assay methods used in the study are shown in Table 3 as extracted from the submissions of the participants. References to the methods used are included in the Reference list.

\subsection{Statistical analysis}

For each assay, the raw responses were plotted against the dilution of the preparation and examined both graphically and using analysis of variance. Groups of raw responses obtained using the same dilution of the same preparation in the same assay were examined for outliers both in terms of the within group variation and in terms of the variation of that group relative to the variation of other groups in the same assay (using the in-house program SCAN (Gaines Das and Rice, 1985)).

In most cases the IL-4 preparations showed a significant regression on dose with a relationship which could be reasonably described using a four parameter logistic function. Where the response showed no regression on dose, as was generally the case for the excipient or for the IL-3 preparations in an assay system which was specific for IL-4 prepara- tions, all such responses were omitted from further analysis. In those assay systems where both IL-3 and IL-4 preparations gave responses which showed a significant relationship with dose, but where the relationship with dose differed markedly between the two types of preparation, the response data for the IL-3 preparation were also deleted from further analysis.

Where assays were carricd out on microtitre plates, and only a single plate was used or each plate included a common standard, individual responses were used for analysis and responses from the single plate were analysed as an assay. If such assays extended over several plates, estimates from different plates for the same preparation were combined as geometric means to give a single estimate for each preparation from each assay. Where assays extended over several plates, each of which did not include a common standard, no allowance could be made for a possible difference between plates and the individual responses from the several plates have been analysed together as a single assay. Some laboratories used a degree of replication of plates and independent dilution series within and between plates; for these assays analysis has been carried out using the mean response within a plate or dilution series.

For other assays, for which detailed information about the assay design was generally limited, all individual responses have been combined and analysed as an assay.

Values for the upper and lower asymptotes of the four parameter logistic function were used to transform the raw responses to logit responses which were linearly related to $\log$ dose. These transformed responses were then analysed by weighted linear 
Table 2

Participants in the study

Ms. Sandra Thomas, Virology Section. Therapeutic Goods Administration Laboratories, P.O. Box 100, Woden. ACT 2606, Australia

Dr. Darryl Maher, Ludwig Institute. Melbourne Tumour Biology Branch. Post Office. Royal Melbourne Hospital, Melbourne. VIC 3050. Austrailia

Dr. Peter Valent, Department of Internal Medicine I, Division of Hematology and Hemostaseology, University of Vienna, Währinger Gürtel 18-20, A-1090 Vienna, Austria

Dr. Elisabeth Payer, VIRCC, Division of Dermatology, University of Vienna Medical School, Brunner Strasse 59, A-1235 Vienna. Austria

Dr. De Groote, Medigenix Diagnostics. Zoning Industrial, 6220 Fleurus. Belgium

Dr. Kent Hayglass, Department of Immunology, University of Manitoba, Basic Medical Sciences Building, 730 William Avenue. Winnipeg, Manitoba R3E OW3. Canada

Dr. H. Ziltener. The Biomedical Research Center. 2222 Health Sciences Mall. UBC Vancouver, British Columbia V6T 1Z3, Canada

Dr. Lars K. Poulsen. National University Hospital, Laboratory of Medical Allergology, Medical Department TTA 7542. Tagnensvej 20. DK-2200 Copenhagen. Denmark

Dr. Pierre Miossec and Miss P. Chomarat. Department of Immunology and Rheumatology, Hôpital Edouard Herriot, 69437 Lyon Cedex, France

Dr. Jacques Grassi, SPI/DRIPP, Bâtiment 136, Commissariat à I'Energie Atomique, CEN Seclay, 91191 Gif-sur-Yvette, Cedex, France

Dr. G. Pawelec. Medizinische Klinik. W-72076 Tübingen. Germany

Dr. U. Fritzsche. Behringwerke AG, Preclinical Research, P.O. Box 1140, Emil-van-Behring-Strasse 76. W-3550 Marburg/Lahn, Germany

Dr. M. Falk, Department of Cell Biology, IBR Forschungs GmbH, Sïdkampen 31, D-3030 Walsrode, Germany

Dr. M. Topp, Department of Hacmatology and Oncology, Benjamin Franklin Klinik. Freie Universität Berlin. Hindenburgdamm 30.12200 Berlin, Germany

Dr. G. Reisbach. GSF Forschungszentrum, Hämatologikum, Marchionini Strasse 25. D-81377. Munich, Germany

Dr. John Sidiropoulos, Clinical Immunology Department, 2nd Medical Department/University. Hippokration Hospital. Thessaloniki. Greece

Dr. S.Z. Ben-Sasson. The Lautenberg Center for General and Tumour Immunology. The Hebrew University - Hadassah Medical School, P.O. Box 1172, Jerusalem 91010, Israel

Dr. Zeev Even-Chen, Sigma Israel Chemicals Lid. (formerly Makor Chemicals Ltd.). P.O. Box 6570, Jerusalem 91064, lsrael

Dr. Luigi Pegoraro. Dipartimento di Scienze Biomediche e Oncologia Umana, Sezione Clinica, Via Genova 3. 10126 Turin. Italy

Professor Francesco Barboni, Director of Clinical Pathology, Malpighi Hospital, Via P. Palagi 9, 40138 Bologna, Italy

Dr. Kenkichi Sugimoto, Department of Physiology and Biochemistry. Faculty of Science. Niigata University. Niigata 950-21, Japan

Dr. K. Tsuji, Department of Pediatrics. Shinsu University School of Medicine. 3-1-1 Asahi. Matsumoto, Japan

Dr. Tomoaki Matsumoto, Department of Child Development, Kumamoto University. Medical School, I- I-1 Honjo. Kumamoto 860. Japan

Drs. Kenrichi Arai and Takashi Yokota, Department of Molecular and Developmental Biology, Institute of Medical Science, University of Tokyo, 4-6-1 Shirokanedai, Minato-ku. Tokyo, Japan

Dr. J. Olobo, Institute of Primate Research, P.O. Box 24481, Karen. Nairobi. Kenya

Dr. G. Wagemaker. Frasmus Universiteit Rotterdam, Hematology. Room H F.F 1314. P.O. Box 1738. 3000 DR Rotterdam, Netherlands

Dr. T. Van Der Pouw-Kraan, Central Laboratory of the Netherlands, Red Cross Blood Transfusion Service, Plesmanlaan 125,1066 CX Amsterdam. Netherlands

Dr. Kirrikant V. Sheth, Iead Immunopathology Section. King Faisal Special Ilospital and Research Centre. Department of Pathology and Laboratory Medicine, P.O. Box 3354, Riyadh 11211, Saudi Arabia

Drs. C. Gutiersez and D. Rivas. Head - Department of Immunology. Hospital Central de Asturias. Celestino Villamil. s/n 33006 Oviedo. Spain

Drs. Nils Lycke and Karin Schön. Department of Medical Microbiology and Immunology. University of Göteborg. Göteborg. Sweden

Dr. John P.A. Bews, CIBA-GEIGY Pharma, R1056.408, CH-4002 Basel, Switzerland

Dr. K. Tullberg, Sandoz AG, Bau 360/307. Postfach. CH-4002 Basel, Switzerland

Dr. R. Klotzbuicher. Roche Diagnostic Systems. Department DDIR-T. Building 205/ab. P.O. Box, CH-4002 Basel. Switzerland

Mrs. L. Page and Mr. C. Bird. Division of Immunobiology, National Institute for Biological Standards and Control, Blanche Lane. South Mimms. Potters Bar. Herts. EN6 3QG, UK

Dr. Colin P. McGuckin, Haematology Division. St. George's Hospital Medical School, Cranmer Terrace. Tooting. London SW17 ORE, UK Professor John Gordon and Miss Anita Katira. Department of Immunology. The Medical School. Vincent Drive, Birmingham B15 2TT. UK

Dr. Peter Openshaw and Andrew Georgiou, Department of Medicine. St. Mary's Hospital Medical School, Norfolk Place. London W2 I PC, UK

Dr. Nydia G. Testa, Paterson Institute for Cancer Research. Christie Hospital. Manchester M20 9BX. UK 
Table 2 (continued)

Dr. Robin Callard, Cellular Immunology Unit, Institute of Child Health, 30 Guilford Street, London WC1N 1AH, UK

Ms. K. Paik and Dr. John McKearn, Searle, 700 Chesterfield Village Parkway, St. Louis, MO 63193, USA

Dr. Marie Rock and Ms. Kathleen Harper, Searle, 4901 Searle Parkway Koom K-224, Skokie, IL 60077, USA

Dr. Steven J. Swanson, Associate Principal Scientist, Schering-Plough Research Institute. 2015 Galloping Hill Road, Kenilworth, NJ 07033-0539, USA

Dr. Jay P. Siegel, FDA, Woodmont II Building, Room 3047 HFM-570, 1401 Rockville Pike, Rockville, MD 20852-1448, USA

Dr. H.L. Spiegelberg, Immunology and Allergy Division, Department of Pediatrics 0609D. University of California, San Diego School of Medicine, San Diego, CA 92093-0609, USA

Dr. John Geigert and Kerri Carter. Immunex Manufacturing Corporation, 51 University Street, Seattle, WA 98101, USA

Dr. William E. Paul and Cynthia Watson, National Institutes of Health, Building 10. Room 11N311, 9000 Rockville Pike, Bethesda, MD 20892, USA

Drs. Monica Tsang and Li Zhou, R \& D Systems Inc., 614 McKinley Place NE, Minneapolis, MN 55413, USA

Mr. Louis Westreich, Schering Plough Research Institute, 1011 Morris Avenue (U-2-A), Union, NJ 07083, USA

Dr. Chun C. Chao, Minneapolis Medical Research Foundation, 914 South 8th Street, D3, Minneapolis, MN 55404, USA

Drs. Terry L. Riss and Rich Moravec, Promega Corporation, 2800 Woods Hollow Road, Madison, WI 5371 l-5399, USA

regression (using an in-house program, WRANL (Gaines Das and Tydeman, 1982)) to give an analysis of variance with an assessment of linearity and parallelism of log dose-logit response lines. Estimates of relative potency were obtained as the displacement of parallel log dose-logit response lines.

In a few cases, for which data were insufficient to permit determination of asymptotes, or for which a four parameter logistic function was not a satisfactory description of the dose-response relationship, the available responses from an apparently linear part of the response range were analysed using the customary methods for parallel line assays.

It has been our experience in many assay systems that the within assay replication is not representative of the total assay variation. The collaborative study design thus included two identical ampoules of one IL-4 preparation, coded G and $M$. The difference between the slopes of these two identical preparations provided an additional measure against which the difference between slopes of non-identical preparations could be assessed. The deviation of the observed ratio of activities of these two identical preparations from the expected value of 1 provided a direct measure of the within assay variability inherent in these systems. The between laboratory variability for estimates of this relative activity, expected to be 1 in all assay systems and laboratories, provided a measure of the minimum variability inherent in this study using these assay systems (inherent study variability, SV).
Estimates of relative potency have been combined as geometric means, and comparisons among them have been made using analysis of variance of the logs of the estimates. Fiducial intervals about mean estimates have been based on the variance of the logs of the estimates combined.

\section{Results}

\subsection{Dose-response relationships}

\subsubsection{Filler alone}

In nearly all assay systems, the excipient preparation gave responses which did not differ significantly from 'control' or zero dose responses and which did not change significantly from one dilution to another and which were therefore omitted from further analysis.

\subsubsection{Interleukin-3 (code F) and interleukin-4 (codes $G-M)$}

In the majority of assay systems the log dose-response relationships were adequately described by a four parameter logistic function and the resulting log dose-logit response lines were approximately linear. For some data, estimation of the asymptotes of the four parameter logistic function was either not possible because of limited response ranges or not satis- 
Table 3

Numbers and types of assays contributed

\begin{tabular}{|c|c|c|c|c|}
\hline Lab. code & Cell line & Measurement of assay ${ }^{3}$ & Sensitivity and range $(/ \mathrm{ml})$ & Standard used \\
\hline \multicolumn{5}{|c|}{ Cell line proliferation bioassays } \\
\hline 1 & CT.h-4S & $\mathrm{H}-\mathrm{Tdr}$ & $10 \mathrm{pg}-1 \mu \mathrm{g}$ & rDNA \\
\hline 3 & TF-I & MTT $^{3}$ & $40 \mathrm{pg}-5 \mathrm{ng}$ & E. coli rDNA \\
\hline 4 & MO7e & H-Tdr & $10 \mathrm{pg}-2 \mathrm{ng}$ & $\mathrm{CHO} /$ yeast rDNA \\
\hline 5 & TF-1 & $\mathrm{MTT}^{3}$ & $100 \mathrm{ng}-1 \mathrm{ng}$ & E. coli rDNA \\
\hline 11 & CT.h-4S & $\mathrm{H}-\mathrm{Tdr}{ }^{3}$ & $1 \mathrm{pg}-10 \mathrm{ng}$ & E. coli $\mathrm{rDNA}$ \\
\hline 13 & TF-1 & H-Tdr & $20 \mathrm{pg}-1 \mathrm{ng}$ & E. coli $\mathrm{rDNA}$ \\
\hline 18 & MO7e & $\mathrm{MTT}^{3}$ & $5 \mathrm{ng}-80 \mathrm{ng}$ & E coli rDNA \\
\hline 24 & CT.h-4S & $\mathrm{H}-\mathrm{Tdr}^{3}$ & $7 \mathrm{pg}-1 \mathrm{ng}$ & E. coli $\mathrm{rDNA}$ \\
\hline \multirow[t]{2}{*}{27} & 123 & $\mathrm{H}-\mathrm{Tdr}^{3}$ & No cross-react. & Cell supernatant \\
\hline & CTLL-2 & $\mathrm{H}-\mathrm{Tdr}^{3}$ & No closs-react. & Cell supernatant \\
\hline \multirow[t]{2}{*}{28} & MO7e 251 & $\mathrm{H}-\mathrm{Tdr}^{3}$ & $25 \mathrm{pg}-1 \mathrm{ng}$ & COS cell supernatant \\
\hline & MO7e 1511 & $\mathrm{H}-\mathrm{Tdr}^{3}$ & $25 \mathrm{pg}-1 \mathrm{ng}$ & COS cell supernatant \\
\hline 29 & TF- 1 & H-Tdr & $350 \mathrm{pg}-10 \mathrm{ng}$ & Yeast rDNA \\
\hline 32 & TF-1 & MTT & $500 \mathrm{pg}-100 \mathrm{pg}$ & None \\
\hline 33 & $\mathrm{TF}-1$ & MTT & $25 \mathrm{pg}-10 \mathrm{ng}$ & E. coli rDNA \\
\hline 39 & CT.h-4S & $\mathrm{MTT}^{14}$ & $2 \mathrm{pg}-300 \mathrm{pg}$ & rDNA \\
\hline 44 & MO7e & $\mathrm{C}$ & I ng-10 ng & rDNA \\
\hline
\end{tabular}

\begin{tabular}{|c|c|c|c|c|}
\hline Lab. code & Assay format & & Sensitivity and range $(/ \mathrm{ml})$ & Standard used \\
\hline \multicolumn{5}{|c|}{ Immunoassays } \\
\hline 4 & IRMA & & $50 \mathrm{pg}-50 \mathrm{ng}$ & CHO rDNA \\
\hline 6 & RIA & & $15 \mathrm{pg}-500 \mathrm{pg}$ & $\mathrm{CHO}$ rDNA \\
\hline 7 & ELISA & & $125 \mathrm{pg}-2 \mathrm{ng}$ & rDNA \\
\hline 8 & ELISA & & $5 \mathrm{pg}-2.5 \mathrm{ng}$ & E. coli rDNA \\
\hline 12 & ELISA & & No data & E. coli $\mathrm{rDNA}$ \\
\hline 13 & ELISA & & $30 \mathrm{pg}-2 \mathrm{ng}$ & $E$. coli $\mathrm{rDNA}$ \\
\hline 15 & RIA & & $60 p g-960 p g$ & E. coli rDNA \\
\hline 16 & ELISA & & $100 \mathrm{pg}-3 \mathrm{ng}$ & rDNA \\
\hline 17 & ELISA & & $31 \mathrm{pg}-2 \mathrm{ng}$ & E. coli rDNA \\
\hline 19 & IRMA & & $5 \mathrm{pg}-500 \mathrm{pg}$ & CHO rDNA \\
\hline 20 & ELISA & & $2.5 \mathrm{U}-10 \mathrm{U}$ & Yeast rDNA \\
\hline 21 & ELISA & & $1 \mathrm{U}-50 \mathrm{U}$ & CHO rDNA \\
\hline 22 & ELISA & & $3.5 \mathrm{pg}-1 \mu \mathrm{g}$ & E. coli $\mathrm{rDNA}$ \\
\hline 25 & ELISA & & $3 \mathrm{pg}-1.5 \mathrm{ng}$ & E. coli $\mathrm{rDNA}$ \\
\hline 26 & ELISA & & $33 \mathrm{pg}-33 \mathrm{ng}$ & E. coli $\mathrm{rDNA}$ \\
\hline 33 & ELISA & & $10 \mathrm{pg}-2.5 \mathrm{ng}$ & $E$. coli $\mathrm{rDNA}$ \\
\hline 35 & ELISA & & $10 \mathrm{pg}-1.25 \mathrm{ng}$ & E. coli $\mathrm{rDNA}$ \\
\hline 37 & ELISA & & $10 \mathrm{pg}-1 \mathrm{ng}$ & CHO rDNA \\
\hline 42 & ELISA & & $30 \mathrm{pg}-1 \mathrm{ng}$ & No data \\
\hline 45 & ELISA & & $100 \mathrm{pg}-10 \mathrm{ng}$ & E. coli $\mathrm{rDNA}$ \\
\hline Lab. code & Assay format & Assay measurement & Sensitivity and range $(/ m 1)$ & Standard used \\
\hline \multicolumn{5}{|l|}{ Others } \\
\hline 2 & Human PBMC & MTT $^{3}$ & $0.1-10 \mathrm{ng}$ & $E$. coli $\mathrm{rDNA}$ \\
\hline 12 & $\mathrm{~T}$ cell lines & $H-T d r^{3}$ & $50 \mathrm{pg}-1.5 \mathrm{ng}$ & rDNA \\
\hline 13 & PHA blasts & H-Tdr & $10 \mathrm{pg}-5 \mathrm{ng}$ & E. coli $\mathrm{rDNA}$ \\
\hline 30 & $\mathrm{~B}$ cclls & CD23 cxpression & $500 \mathrm{pg} 200 \mathrm{ng}$ & E. coli rDNA \\
\hline 36 & CCL- 185 & Colonies $^{3}$ & $10 \mathrm{pg}-10 \mathrm{ng}$ & E. coli rDNA \\
\hline 41 & B cells & $\mathrm{H}-\mathrm{Tdr}$ & $25 \mathrm{pg}-100 \mathrm{ng}$ & rDNA \\
\hline 48 & RAMOS, G6.C10 & CD23 expression & $100 \mathrm{pg}-2 \mathrm{ng}$ & Yeast rDNA \\
\hline
\end{tabular}


factory, and analyses were carried out using the linear part of log dose-raw response relationships.

The majority of the cell line bioassays were not specific for either the IL-3 or the IL-4 preparations. Where significant cross-reactivity was seen (TF1 cell line in laboratories $3,4,5,13,29,32$ and 33 and MO7e cell line in laboratories 4, 18, 28 and 44), the dose levels, and in some cases the form of the dose-response relationships tended to be very different. In these cases the data for the IL-3 preparations were analyzed separately from those for the IL-4 preparations.
Marked anomalies in estimates or within laboratory variances were noted in some assays and in subsequent discussions where deletions of anomalies are noted this will refer to cell line assays in laboratories $11,12,28,30,41$, preparation $\mathrm{L}, \mathrm{H}$ and in-house standard in some assays from laboratory 13 , and immunoassays in laboratories $21,25,35$, a few assays in laboratory 8 and preparation $\mathrm{H}$ in assay 5 , laboratory 33 .

Data from laboratories 17, 20, 27 and the TF1 cell assays from laboratory 34 and from the IL-4 preparation from laboratory 44 have also been excluded

Table 4

Laboratory geometric mean potency of the various ampouled preparations of IL-4 expressed as international units of $88 / 656$ per ampoule of the ampouled preparation and of the various house standards of IL-4 expressed as nominal ng of 88/656 (assuming one ampoule to contain $100 \mathrm{ng}$ ) per 'ng' of house standard

\begin{tabular}{|c|c|c|c|c|c|c|}
\hline Assay & Laboratory code & $\begin{array}{l}88 / 682 \\
\mathrm{H}\end{array}$ & $\begin{array}{l}89 / 508 \\
\text { J }\end{array}$ & $\begin{array}{l}89 / 668 \\
\mathrm{~K}\end{array}$ & $\begin{array}{l}92 / 576 \\
\mathrm{~L}\end{array}$ & In-house Standard \\
\hline \multicolumn{7}{|c|}{ Cell line assays } \\
\hline CT45_3H & 01 & 246 & 7696 & 10896 & 271 & \\
\hline PBMC_MT & 02 & 770 & 7911 & 4912 & 474 & 6 \\
\hline TFl_MTT & 03 & 183 & 4298 & 7793 & 616 & 51 \\
\hline MO7E_3H & 04 & 280 & 5602 & 10574 & 704 & 72 \\
\hline TF1_3H & 04 & 387 & 4055 & 6254 & 1160 & 168 \\
\hline TF1_MTT & 05 & 244 & 9699 & 9097 & 518 & 42 \\
\hline CT45_3H & $11^{*}$ & 169 & 39786 & 30806 & 274 & 32 \\
\hline $\mathrm{T} 45 \_\overline{3} \mathrm{H}$ & $12^{*}$ & 376 & 8497 & 5464 & 590 & 287 \\
\hline T46_3H & $12 *$ & 295 & 10372 & 8151 & 691 & 234 \\
\hline TK2_3H & $12 *$ & 228 & 7515 & 5913 & 517 & 225 \\
\hline PHA_3H & 13 & 337 & 4320 & 2365 & 518 & 25 \\
\hline $\mathrm{TF} 1 \_3 \mathrm{H}$ & 13 & 196 & 6746 & 9996 & 760 & 11 \\
\hline MO7E_MT & 18 & 152 & 17219 & 13647 & 955 & \\
\hline CT45_3H & 24 & 446 & 5815 & 7358 & 655 & 9 \\
\hline MO7E1_3 & $28^{*}$ & 123 & 40452 & 80886 & 1964 & \\
\hline MO7E2_3 & $28^{*}$ & 119 & 12219 & 6159 & & 346 \\
\hline $\mathrm{TF} 1 \_3 \mathrm{H}$ & 29 & 233 & 8852 & 10828 & 743 & \\
\hline B_LY & $30^{*}$ & 512 & 19678 & 9674 & 950 & 2011 \\
\hline B_SN & $30^{*}$ & 972 & 11765 & 9172 & 1096 & \\
\hline TF1_MTT & 32 & 677 & 22741 & 21741 & 1223 & \\
\hline TF1_MTT & 33 & 323 & 8020 & 9357 & 513 & 1827 \\
\hline $\mathrm{COL}^{-}$ & 36 & 160 & 0 & 396 & 29093 & 28 \\
\hline BM_Hu4 & 39 & 300 & 8713 & 6922 & 353 & 85 \\
\hline B_3 & $41^{*}$ & 445 & 12067 & 9349 & 479 & 1144 \\
\hline Ram_CD2 & 48 & 520 & 12968 & 7937 & 1007 & 51000 \\
\hline \multirow{2}{*}{\multicolumn{2}{|c|}{$\begin{array}{l}\text { Geometric mean of laboratory means of } \\
\text { immunoassays after the deletions * }\end{array}$}} & 321 & 7874 & 8508 & 677 & \\
\hline & & $244-423$ & $5850-10600$ & $6339-11420$ & $635-857$ & \\
\hline \multicolumn{2}{|c|}{ Interval as $\%$ mean } & $76-132$ & $74-135$ & $75-134$ & $79-127$ & \\
\hline
\end{tabular}




\begin{tabular}{|c|c|c|c|c|c|c|}
\hline Assay & Laboratory code & $\begin{array}{l}88 / 682 \\
H\end{array}$ & $\begin{array}{l}89 / 508 \\
J\end{array}$ & $\begin{array}{l}89 / 668 \\
K\end{array}$ & $\begin{array}{l}92 / 576 \\
\mathrm{~L}\end{array}$ & In-house Standard \\
\hline \multicolumn{7}{|c|}{ Immunoassays } \\
\hline IRMA4 & 04 & 298 & 10612 & 10958 & 602 & 92 \\
\hline RIA & 06 & 333 & 8565 & 6256 & 371 & 37 \\
\hline EL4G & 07 & 78 & 5964 & 9188 & 784 & 232 \\
\hline EL4RD & 07 & 191 & 8382 & 6700 & 458 & 33 \\
\hline EL4 & 08 & 806 & 2303 & 1610 & 109 & 74 \\
\hline EL4 & 13 & 276 & 15480 & 6844 & 532 & 35 \\
\hline EL4 & 16 & 664 & 8232 & 3743 & 524 & 25 \\
\hline IRMA & 19 & 483 & 11844 & 9148 & 497 & 64 \\
\hline EL4 & $21^{*}$ & 253 & 10912 & 21635 & 580 & 3054 \\
\hline EL4 & 22 & 416 & 6179 & 5271 & 395 & 62 \\
\hline EL4 & $25^{*}$ & 265 & 13059 & 14516 & 727 & 72 \\
\hline EL4 & 26 & 4466 & 11744 & 9527 & 1187 & 46 \\
\hline EL4 & $33^{*}$ & 658 & 2893 & 3355 & 218 & 15 \\
\hline EL4 & $35^{\circ}$ & 197 & 499 & 3800 & 262 & 41 \\
\hline EL4 & 37 & 593 & 8964 & 7195 & 790 & 104 \\
\hline EL4 & 42 & 576 & 2458 & 2434 & 208 & 166 \\
\hline EL4 & 45 & 466 & 7981 & 10980 & 538 & 50 \\
\hline \multirow{2}{*}{\multicolumn{2}{|c|}{$\begin{array}{l}\text { Geometric mean of laboratory means of } \\
\text { immnoassays after deletions * }\end{array}$}} & 428 & 7161 & 6316 & 461 & \\
\hline & & $256-715$ & $5082-10090$ & $4611-8652$ & $334-637$ & \\
\hline \multicolumn{2}{|c|}{ Interval as $\%$ mean } & $60-167$ & $71-141$ & $73-137$ & $72-138$ & \\
\hline \multirow{2}{*}{\multicolumn{2}{|c|}{$\begin{array}{l}\text { Geometric mean of all laboratory geometric } \\
\text { means ( } 95 \% \text { confidence limits) }\end{array}$}} & 339 & 6457 & 7507 & 618 & 101 \\
\hline & & $273-422$ & $3701-11265$ & $5812-9697$ & $476-802$ & $54-186$ \\
\hline \multicolumn{2}{|c|}{ Interval as $\%$ mean } & $80-124$ & $57-174$ & $77-129$ & $77-130$ & $54-185$ \\
\hline
\end{tabular}

from further statistical analysis due to lack of species cross-reactivity in laboratories 20 and 27 and nonquantifiable data in laboratories 17, 34 and 44 .

\subsubsection{Cell line assays and immunoassays}

The IL-4 preparations were examined in 23 cell line assay systems. In ten of these systems, no consistent significant differences were detected between the dose-response lines for the IL- 4 preparations. In the remaining systems $\mathbf{J}$ or both $\mathrm{J}$ and $\mathrm{K}$ gave different dose-response lines from the other IL-4 preparations; in two of these the dose-response line for $\mathrm{L}$ and in two the dose-response line for $\mathrm{H}$ was similar to that for $\mathbf{J}$. Under the conditions of laboratory 4, both the TF1 cell line and the MO7e cell line distinguished between the IL-4 preparations with, in the case of the MO7e cells, the dose-reponse line for $\mathrm{J}$ being flattest, those for $\mathrm{H}$ and $\mathrm{K}$ being somewhat flat, those for $\mathrm{G}$ and $\mathrm{M}$ being steeper and that for $L$ being steepest; in the case of the TF1 cells, the dose-response lines for $\mathrm{J}$ and $\mathrm{K}$ were flat, those for $\mathrm{G}$ and $\mathrm{M}$ were intermediate and those for $\mathrm{H}$ and $\mathrm{L}$ were steep.

The IL-4 preparations were examined in $17 \mathrm{im}$ munoassay systems. In four of these the ampouled preparations were examined for the most part at single dilutions so that dose-response lines were not available for comparison and in five systems no consistent significant differences between the IL-4 preparations were detected. In five of the remaining systems $\mathrm{J}$ and $\mathrm{K}$ gave different dose-response lines from some or all of the other IL-4 preparations. Preparations $\mathrm{G}(=\mathrm{M}), \mathrm{H}$ or $\mathrm{L}$ were also distinguished by some assay systems. 
4.1.3.1. Estimates of the relative activity of the $I L-4$ preparations in terms of one another. Comparisons of each of the ampouled preparations of IL-4 with the interim standard $88 / 656(\mathrm{G}$ and $\mathrm{M})$ are shown in Fig. 4 and summarized in Table 4.

For each of these comparisons, estimates of relative activity obtained using immunoassays were at least 10-fold more variable between laboratories than estimates for the coded duplicates, i.e., the inherent study variability (SV).

Except for the comparison of $92 / 576$ (L) with $88 / 656$, the between laboratory variability for estimates from all cell line assays was about twice that of the SV. However, the between laboratory variabilities for estimates from TF1 cell line assays only, comparing $88 / 682(\mathrm{H}), 89 / 668(\mathrm{~K})$ or $92 / 576(\mathrm{~L})$ with $88 / 656$, were similar to the SV. For each of these comparisons except $88 / 682(\mathrm{H})$ with $88 / 656$ ( $\mathrm{G}$ and $\mathrm{M}$ ), the preparation ( $\mathrm{J}, \mathrm{K}$ or $\mathrm{L}$ ) appeared to be more biologically active than immunologically active. The ratios of biological to immunological activity, using all cell line assays and all immunoassays were $0.74,1.60,1.48$ and 1.52 for $\mathrm{H}, \mathrm{J}, \mathrm{K}$ and $\mathrm{L}$ respectively.

4.1.3.2. Comparison of $I L-4$ preparations with the various in-house standards. Comparisons of in-house standards of IL-4 with 88/656 (G and M) are summarized in Table 4. Estimates differed even more widely between assays than did estimates for house standards of IL-3 (between laboratory variability some 30 times the SV for IL-4, some 15 times the SV for IL-3). However, considered overall, there was broad agreement that one ampoule of $88 / 656$ contained $0.1 \mu \mathrm{g}(100 \mathrm{ng})$ of IL-4.

\subsection{Stability}

Ampoules of $88 / 656$ which had been stored at elevated temperatures for more than 5 years were compared with ampoules of 88/656 stored continuously at $-20^{\circ} \mathrm{C}$ using three TF 1 cell line assays and in two MO7e cell line assays. Results from samples stored at $4^{\circ} \mathrm{C}$ or $37^{\circ} \mathrm{C}$ did not differ significantly from those obtained using samples stored continuously at $-20^{\circ} \mathrm{C}$ or from one another. Samples stored at $56^{\circ} \mathrm{C}$ showed a significant loss of activity which may also reflect greater difficulty in reconstitution

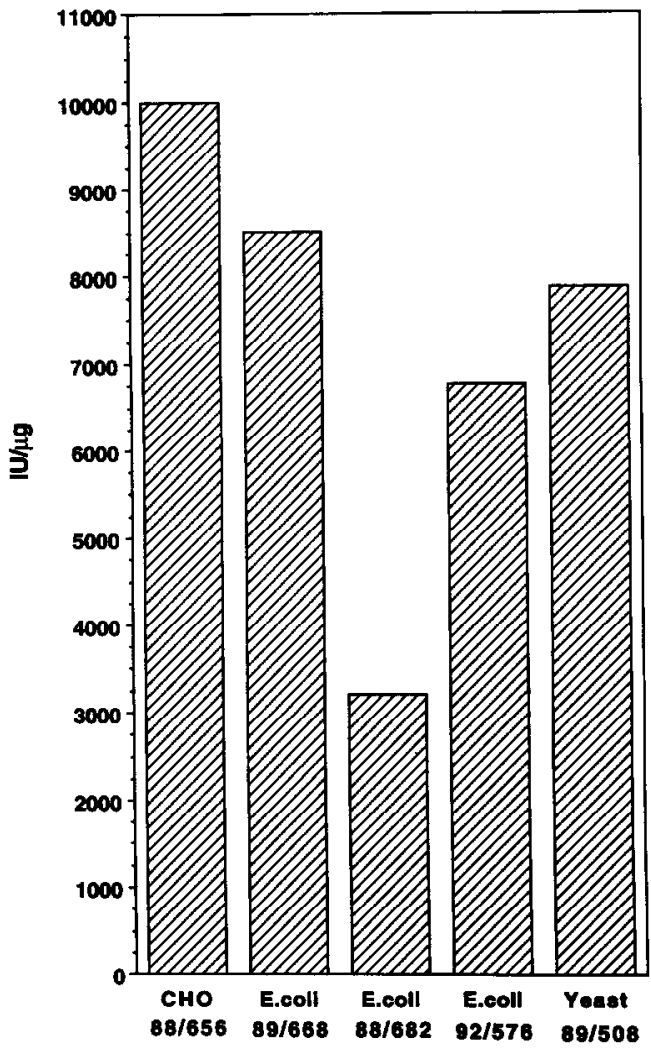

Fig. 1. Relative biological specific activities of recombinant IL-4 preparations included in the study.

after extended storage at this temperature. Failure to detect any loss of activity for samples stored at $4^{\circ} \mathrm{C}$ or $37^{\circ} \mathrm{C}$ suggests that there is no significant instability.

\section{Discussion}

The foremost result generated from the data provided by this study is that in the majority of the assay systems for IL-3 and IL-4 cannot be validly compared with one another and furthermore that the relative activities of pairs of IL-4 preparations may differ depending on the assay system and may not reflect the relative mass contents of ampoules.

This data illustrates a fundamental property of recombinant materials that is not generally taken into account, namely that recombinant preparations of the same mass may have very different biological specific activities (Fig. 1). 


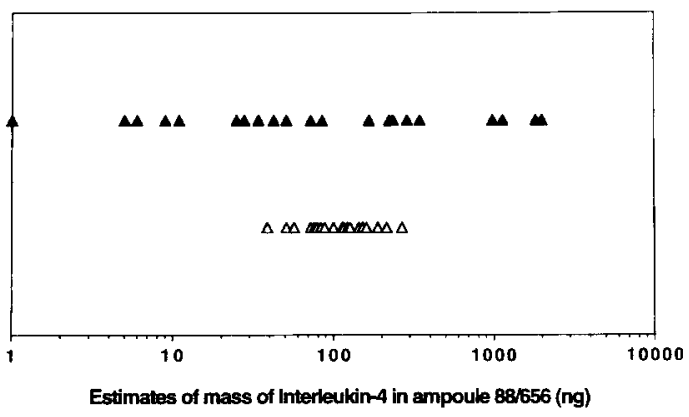

Fig. 2. Relative estimate of the mass of IL-4 in ampoule $88 / 656$ by bioassay using either the various in-house standards of participants $(\Delta)$ or by comparison with the internal duplicate $88 / 656$ ampoule $(\Delta)$.

This emphasizes the need for a potency standard to be calibrated in biological units and not mass units as these are not equivalent between different recombinant and natural materials.

The need for a single potency standard is evident when comparing the estimates of each preparation to the myriad of in-house standards currently being used. The data in this study illustrate that the interlaboratory variation using in-house standards is at least 5-10 times that using any of the single ampouled preparations included in the study, i.e., two laboratories can be different by 5-10-fold when estimating the $\mathrm{IL}-4$ content of the same preparation (Fig. 2). The use of a single reference standard substantially decreases this inter-laboratory variation, e.g., the reduction in variation when $89 / 508, \mathrm{~J}$, is compared with $88 / 656, \mathrm{G}$ and $\mathrm{M}$, rather than with the in-house standards.

It is also clear that estimates of potency derived from immunoassays consistently disagree with those derived from bioassays. The large differences between estimates from different immunoassay systems, suggest that the specific antibody pairs used in each assay recognise different cytokine preparations to unique and variable degrees (Fig. 3).

The results from this study serve as a reminder that immunoassays may provide precise comparisons of identical preparations or of preparations
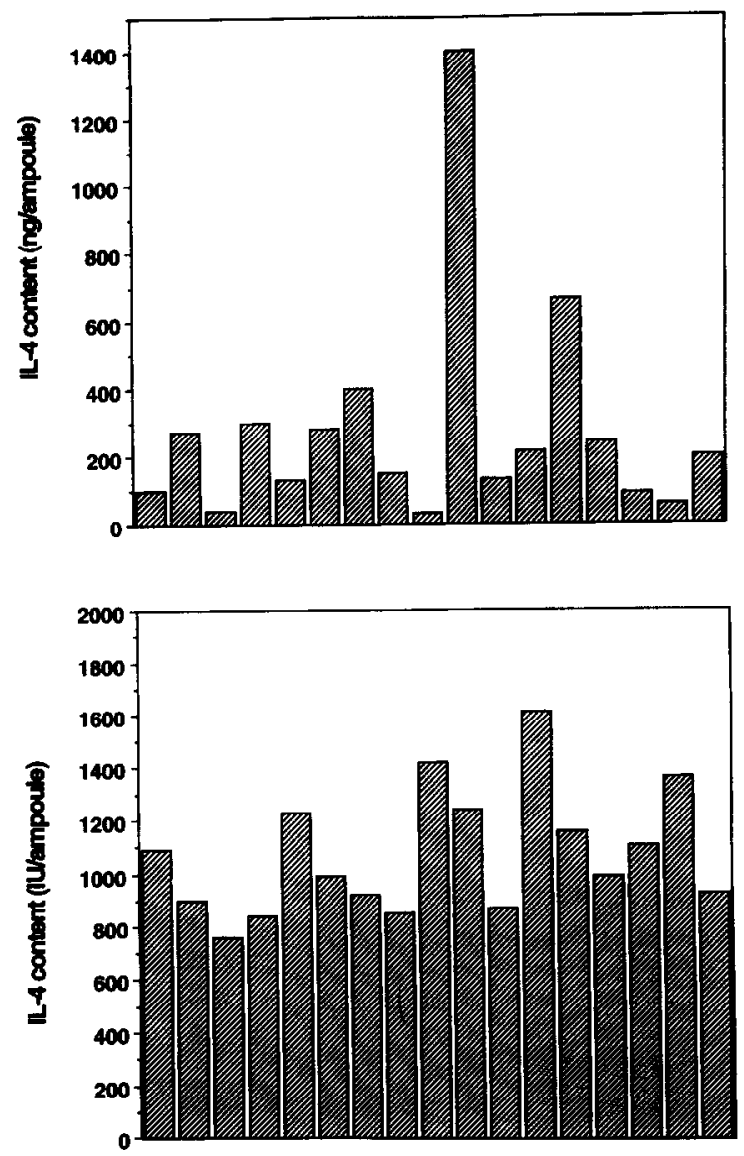

Fig. 3. Immunoassay estimates of IL-4 levels of $88 / 656$ using either the various in-house standards of participants (upper panel) or by comparison with the internal duplicate $88 / 656$ ampoule (lower panel).

which are seen to be identical antigenically, but that the antigenic structures recognized by the immunoassay may not reflect biological activity and may not be valid for comparing interleukins derived from different sources (Figs. 1 and 3 ).

The relative activities of the $\mathrm{IL}-4$ preparations were not consistent in all assay systems. Estimates for $89 / 508, \mathrm{~J}$, compared with $88 / 656, \mathrm{G}$ and $\mathrm{M}$, or $92 / 576$, L, had larger inter-laboratory variability than other comparisons. The dose-response relations

Fig. 4. Estimates of relative activity of the preparations indicated expressed in international units (IU) of IL-4 in comparison to preparation $88 / 656$. Each box denotes a single assay estimate. Black boxes denote bone marrow assays. stippled boxes immunoassays and plain boxes cell line bioassays. 

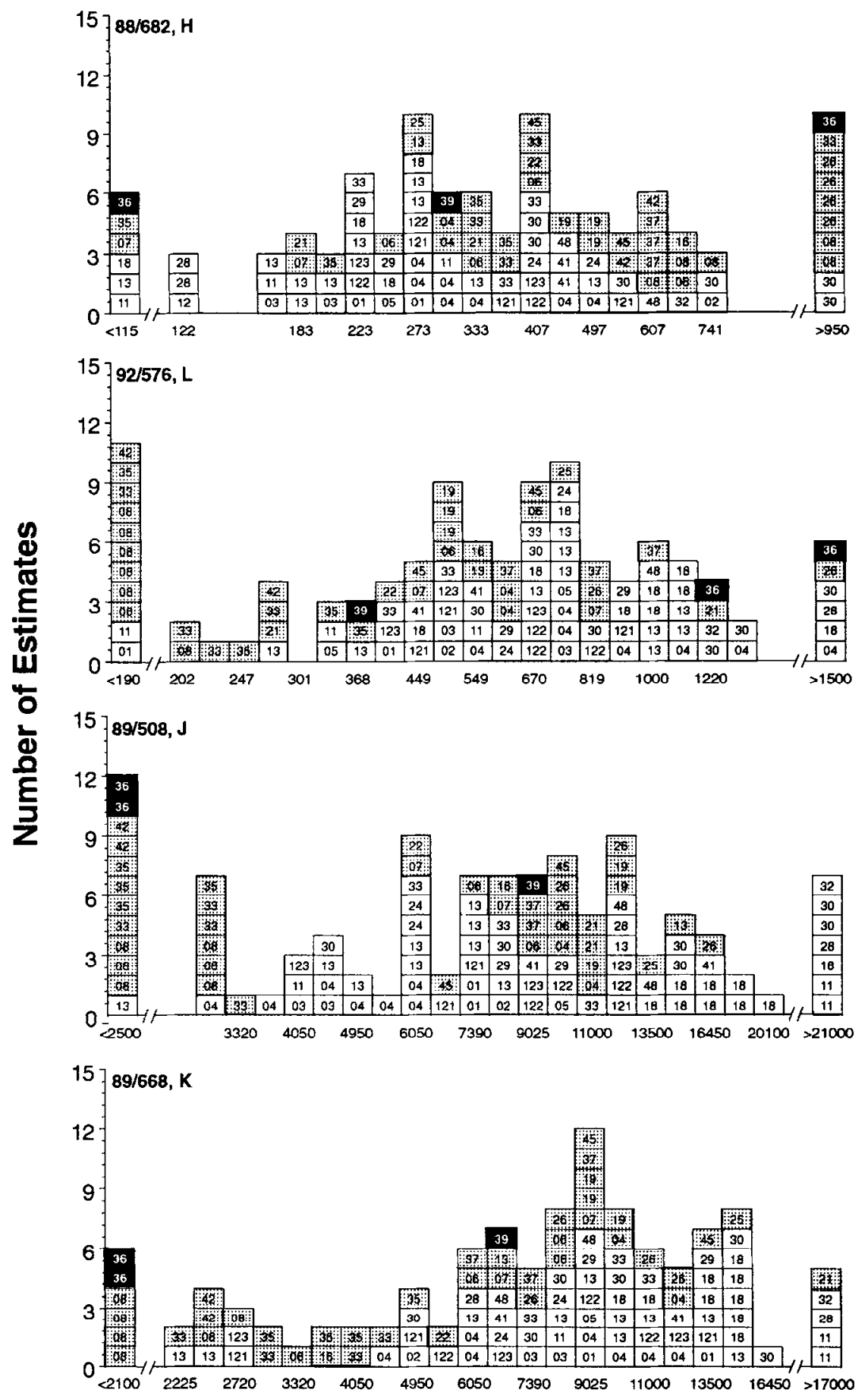

IU/ampoule 
for $89 / 508, \mathrm{~J}$, were also notable for their differences from the other IL-4 preparations (with the possible exception of $89 / 668, \mathrm{~K}$ in some systems). It is also noted that $89 / 508, \mathrm{~J}$, is the only $\mathrm{IL}-4$ preparation to have been mutated in specific regions, although it is not known if this accounts for the observed differences. There were no apparent consistent differences observed among the other preparations. The IL-4 preparation $88 / 656, \mathrm{G}$ and $\mathrm{M}$, appears equally suitable to any of the other preparations, with the possible exception of $89 / 508$, J, to serve as an international standard, and no problems have been reported with its use as an interim standard since 1988. It was therefore agreed that $88 / 656$ be established as the international standard for IL- 4 and that it be assigned the unitage of $1000 \mathrm{IU} /$ ampoule (the unitage adopted for its use as an interim standard) (Fig. 4).

\section{Conclusions}

The data contributed to this study illustrate the need for a standard for IL-4 calibrated in specific biological potency units. The results of this study also provide confirmation of the accuracy and precision of bioassays used for calibration purposes and illustrate the possible difficulties in calibration which may arise if the differences in biological and immunological activities are ignored.

Based on the results of this study the preparation in ampoules coded 88/656 was established by the WHO Expert Committee on Biological Standardization (ECBS) as the international standard for IL-4 with an assigned potency of $1000 \mathrm{IU}$. There are approximately 3400 ampoules of $88 / 656$ available for distribution. These materials are stored at the National Institute for Biological Standards and Control and are available for world-wide distribution.

\section{Acknowledgements}

We thank Deborah Richards for processing this report. We acknowledge Gill Creeber for data processing and the Standards Processing Division, in particular Dr. Peter Dawson, for the preparation of the ampouled materials. We would also like to thank all the participants of this study and the companies who generously donated materials - Schering Plough Corporation, USA; Immunex Corporation, USA; Sandoz, Switzerland; Glaxo, UK; and Innogenetics. Belgium.

\section{References}

Avanzi, G.C., Lista, P., Giovinazzo, B., Miniero, R., Saglio, G., Benetton, G., Coda, R., Cattoretti, G. and Pegoraro, L. (1988) Selective growth response to IL-3 of a human leukaemic cell line with megakaryoblastic features. Br. J. Haematol. 69, 356.

Defrance, T., Fluckiger, A.C., Rossi, J.F., Magaud, J.P., Sotto, J.J. and Banchereau. J. (1992) Antiproliferative effects of interleukin-4 on freshly isolated non-Hodgkin Inalignant Blymphoma cells. Blood 79, 990.

Gilleece, M.H., Scarffe, J.H., Ghosh. A., Heyworth, C.M., Bonnem, E., Testa. N., Stern, P. and Dexter, T.M. (1992) Recombinant human interleukin-4 (IL-4) given as daily subcutaneous injections - A phase I dose toxicity trial. Br. J. Cancer 66, 204.

Golumbek, P.T.. Lazenby, A.J., Levitsky, H.I., Jaffee, L.M., Karasuyama, H., Baker, M. and Pardoll. D.M. (1991) Treatment of established renal cancer by tumour cells engineered to secrete interleukin-4. Science 254, 713.

Howard, M., Farrar, J.. Hilfiker, M.. Johnson. B.. Takatsu. K., Hamaoka, T. and Paul, W.E. (1982) Identification of a T cell derived B cell growth factor distinct from interleukin 2. J. Exp. Med. 155, 914.

Margolin, K., Aronson, F.R., Sznol, M., Atkins, M.B., Gucalp. R., Fisher. R.I.. Sunderland. M.. Doroshow. J.H., Ernest, M.L. and Mier. J.W. (1994) Phase II studies of recombinant human interleukin-4 in advanced renal cancer and malignant melanoma. J. Immunother. Emphasis Tumor Immunol. 15, 147.

Ohara, J., Coligan, J., Zoon, K., Maloy, W.L. and Paul. W.E. (1987) High-efficiency purification and chemical characterization of B cell stimulatory factor- 1 /interleukin-4. J. Immunol. $139,1127$.

Ohara. J. (1988) Interleukin-4: Molecular structure and biochemical characteristics, biological function, and receptor expression. Year Immunol. 5. 126.

Siegel. J.P. and Mostowski, H.S. (1990) A bioassay for the measurement of human interleukin-4. J. Immunol. Methods 132, 287.

Toi, M. Bicknell, R. and Harris, A.L. (1992) Inhibition of colon and breast carcinoma cell growth by interleukin-4. Cancer Res. 52, 275.

Topp, M.S., Koenigsmann, M., Mire-Sluis, A., Oberberg. D.. Eitelbach, F.. Marschall. Z. von, Notter, M., Reufi. B., Stein, H., Thiel, E. and Berdel, W.E. (1993) Recombinant human interleukin-4 inhibits growth of some human lung tumor cell lines in vitro and in vivo. Blood 82, 2837.

Yokota. T., Otsuka, T.. Mosmann. T., Banchereau, J., Defrance. 
T., Blanchard, D., de Vries, J.E., Lee, F. and Arai, K. (1986) Isolation and characterization of a human interleukin cDNA clone, homologous to mouse B-cell stimulatory factor-1, that expresses B-cell- and T-cell-stimulatory activities. Proc. Natl. Acad. Sci. USA 83, 5894.

Yokota, T., Arai, N., DeVries, J., Spitz, H., Banchereau, J..
Zlotnick, A., Rennick. D., Howard, M., Takebe. Y., Miyatakes, L.F. and Arai, F. (1988) Molecular biology of interleukin-4 and interleukin-5 genes and biology of the product that stimulate B cells, $T$ cells and hematopoietic cells. Immunol. Rev. 102, 172. 